\title{
Uneconomical game cropping in a community-based conservation project outside the Serengeti National Park, Tanzania
}

\author{
Tomas Holmern, Eivin Røskaft, Job Mbaruka, Samson Y. Mkama and John Muya
}

\begin{abstract}
Since 1993 the Serengeti Regional Conservation Project (SRCP) in Tanzania has conducted a game cropping operation (the commercial utilization of wild animal populations in natural habitats) in areas immediately outside the Serengeti National Park in order to provide adjacent villages with incentives to abstain from illegal hunting. In this study we carry out a comparative economic analysis of the SRCP cropping operation and illegal hunting. The extent of illegal hunting was mapped by utilising questionnaires distributed to Village Game Scouts employed in five of the Project villages. Our research indicates that the cropping operation is not economically sustainable and makes only a minor economic contribution to the Project villages compared to
\end{abstract}

\section{Introduction}

Community-based conservation (CBC) is now a well established approach to biodiversity conservation throughout Africa (Kiss, 1990; Hulme \& Murphree, 2001), although the success of CBC in achieving effective results is being debated (Hackel, 1999; Songorwa et al., 2000; Newmark \& Hough, 2000; Adams \& Hulme, 2001). Conservation benefits to communities from $\mathrm{CBC}$ in eastern and southern Africa are generally acquired through the retention of revenues from the tourist industry and/or different types of wildlife utilization schemes (Child, 1996; Lewis \& Alpert, 1997; Bergin, 2001).

Several of the CBC projects in Tanzania emphasize the sustainable use of surrounding wildlife resources (Walsh 1998; Songorwa, 1999). Immediately outside the Serengeti National Park, the Serengeti Regional Conservation Project (SRCP) has run a game cropping (the commercial utilization of wild animal populations in natural habitats) operation since 1993 in the adjacent Grumeti and Ikorongo Game Reserves and neighbour-

Tomas Holmern ${ }^{1}$ (Corresponding author), Eivin Roskaft ${ }^{1}$, Job Mbaruka Samson Y. Mkama and John Muya Serengeti Regional Conservation Project, P.O. Box 32, Mugumu, Serengeti District, Tanzania

${ }^{1}$ Present address: Department of Zoology, Norwegian University of Science and Technology, N-7491 Trondheim, Norway. E-mail: tomas.holmern@chembio.ntnu.no

Received 20 August 2001. Revision requested 11 February 2002. Accepted 29 May 2002 illegal hunting. Furthermore, cropping quotas are small, utilization of quotas low, and the level of community involvement limited. Illegal hunting was extensive around both Project and other villages. We suggest that SRCP discard the inefficient cropping operation and instead concentrate on diversifying income opportunities for the Project villages.

Keywords Community-based conservation, game cropping, hunting, Serengeti, Tanzania.

This paper contains supplementary material that can only be found online at http:/ /journals.cambridge.org

ing Ikona Wildlife Management Area to provide communities with incentives to abstain from illegal hunting (Mbano et al., 1995). The Norwegian Agency for Development Cooperation and the Tanzanian government has supported SRCP since 1987, and in the period 1998-2002 US $\$ 330,000$ has been provided annually (Havnevik et al., 2001).

Illegal hunting is considered a serious threat to the Serengeti ecosystem and has reduced the populations of buffalo Syncerus caffer by $50-90 \%$ in parts of their range (Dublin et al., 1990). Other resident wildlife, such as giraffe Giraffa camelopardis, impala Aepyceros melampus and topi Damiliscus korrigum are also experiencing heavy hunting pressure in areas close to the protected area boundaries (Campbell \& Borner, 1995; Hofer et al., 1996). The main hunting method in the Serengeti is the use of snares, but night hunting with torches and hunting dogs has also become common (Arcese et al., 1995; Holmern, 2000). Illegal hunting is highly profitable over large tracts of the protected area (Hofer et al., 2000).

In this study we use the SRCP and other areas outside the Serengeti National Park as a case study. We conduct a comparative economic analysis of the SRCP cropping operation and illegal hunting, in order to assess the economic sustainability of the two systems.

\section{Study area}

The study was conducted in Bunda and Serengeti Districts adjacent to the Western Corridor of the Serengeti National Park (Fig. 1). The study area lies at 


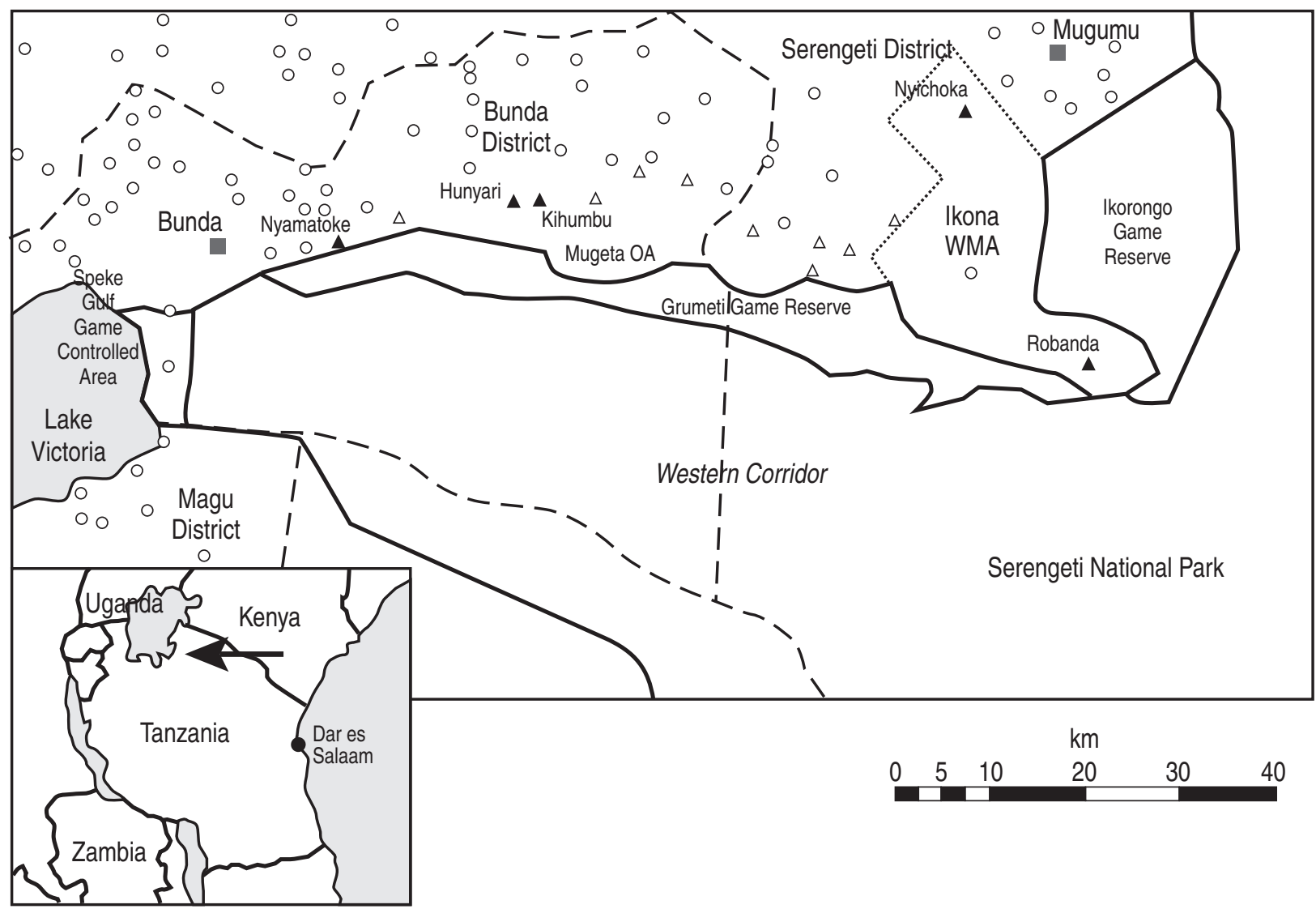

Fig. 1 The Western Corridor of the Serengeti National Park with the approximate locations of villages. Triangles are the 14 project villages and filled triangles indicate the five project villages included in the survey of illegal hunting by Village Game Scouts. Squares are district administrative towns and open circles are all other villages. The dashed line represents district boundaries, thick lines denote the protected areas and the dotted line represents Ikona Wildlife Management Area. The arrow on the inset map indicates the location of the main figure.

altitudes of $920-1,500 \mathrm{~m}$, the mean annual temperature is $21.7^{\circ} \mathrm{C}$, and the mean annual total precipitation varies from $800 \mathrm{~mm}$ in the east to $1,050 \mathrm{~mm}$ in the northwest (Campbell \& Hofer, 1995). Serengeti District contains relatively intact thorn tree woodlands and plains (with species of Acacia, Comiphora, Ficus, Combretum and Podocarpus) in Ikona Wildlife Management Area (Herlocker, 1976). In Bunda District the areas to the west are largely treeless, and extensive areas adjacent to the Grumeti Game Reserve and Serengeti National Park have been converted to agriculture.

The Western Corridor of the Serengeti National Park is characterized by the annual migration of wildebeest Connochaetes taurinus (McNaughton \& Banyikwa, 1995). Normally the migratory herds reach this area in May or June. The duration of their stay depends on rainfall, but usually the herds have moved to their dry season areas in the northern Serengeti and Masai Mara National Reserve by August (Maddock, 1979).

Bunda and Serengeti Districts had human populations of 200,870 and 113,284 , respectively, in the last National
Census in 1988, and an average annual population increase of 3.1\% (Bureau of Statistics, 1988). Tanzania is poor economically and in 2000 had a gross per capita income of US $\$ 270$ (World Bank, 2000). Most of the multi-ethnic communities in the study area practice subsistence farming, complemented to varying degrees by livestock keeping and illegal hunting (Mtoni, 1999).

\section{Materials and methods}

\section{The SRCP cropping operation}

The cropping operation, which began in 1993, includes 14 villages in Bunda and Serengeti Districts (Fig. 1). The aim of the cropping operation is to provide communities with legal meat and to 'play a central role in the economic development of the project's villages' (SRCS, 1995). The species cropped (wildebeest, zebra Equus burchelli, and topi) were chosen on the basis of their potential meat yield and skin value. Topi was first added to the quota in 1995 (Table 1). SRCP is allocated a quota 
Table 1 The quota, number cropped and percentage of the quota utilized for the three species (wildebeest, zebra and topi), in the game cropping scheme from 1993 to 1999.

\begin{tabular}{|c|c|c|c|c|c|c|c|c|c|}
\hline \multirow[b]{2}{*}{ Year } & \multicolumn{3}{|c|}{ Wildebeest } & \multicolumn{3}{|l|}{ Zebra } & \multicolumn{3}{|l|}{ Topi ${ }^{c}$} \\
\hline & Quota & Cropped & $\%$ & Quota & Cropped & $\%$ & Quota & Cropped & $\%$ \\
\hline 1993 & 480 & 94 & 19.6 & 192 & 63 & 32.8 & & & \\
\hline 1994 & 700 & 108 & 15.4 & 90 & 25 & 27.8 & & & \\
\hline 1995 & 592 & 227 & 38.3 & 64 & 29 & 45.3 & 39 & 22 & 56.4 \\
\hline 1996 & 500 & 117 & 23.4 & 70 & 70 & 100 & 50 & 50 & 100 \\
\hline $1997^{a}$ & 250 & - & - & 140 & - & - & 100 & - & - \\
\hline 1998 & 300 & 108 & 36.0 & 180 & 60 & 33.3 & 100 & 42 & 42.0 \\
\hline $1999^{\mathrm{b}}$ & 210 & - & - & 140 & - & - & 70 & - & - \\
\hline
\end{tabular}

a Data for number cropped were not available for 1997.

${ }^{b}$ Records of the number of animals cropped was only available up to November 1998.

cTopi was only added to the quota from 1995 onwards.

directly by the Wildlife Department and it is divided equally among the Project villages. The cropping team are required to follow the normal hunting season (1 July-31 December), but can hunt outside the season with permission from the Wildlife Department.

The cropping takes place mainly in Grumeti Game Reserve $\left(c .416 \mathrm{~km}^{2}\right)$ and Ikona Wildlife Management Area (c. $600 \mathrm{~km}^{2}$ ) (Fig. 1), and occasionally in Ikorongo Game Reserve $\left(c .563 \mathrm{~km}^{2}\right)$. Animals are shot during the day from a four-wheel drive vehicle and, because the meat is consumed locally, it is not subject to any health rules. The Natural Resource Committee in each of the Project villages organizes the sale and determines the price of the fresh meat (in the range US \$0.27-0.40 per kg). The skins are processed by local skinners. All expenses associated with the cropping operation are covered by $\mathrm{SRCP}$, and all income is retained in the Project villages. The income has been used for reducing the tax burden in Project villages, in addition to building classrooms, dispensaries, and houses for nurses and teachers.

\section{Survey of illegal hunting}

To document patrol efforts and illegal hunting Village Game Scouts (VGS) in five Project villages (Fig. 1) filled out questionnaires during patrols from December 1998 to August 1999. The five participating Project villages were chosen because they had functioning VGS teams and were evenly distributed within the study area. The questionnaire (Appendix 1), written in KiSwahili, contained 20 questions on the patrol, arrested hunter(s), methods of hunting, and the species recovered. No differentiation was made between porters and hunters. We provided the VGS with training in how to fill out the questionnaire, and held follow-up meetings with them, with the help of a local interpreter, two times per village per month for the first 3 months and the last
2 months of the survey. During these follow-up meetings T.H. collected the questionnaires and all hunting equipment seized by the VGS. In the period when T.H. was absent hunting questionnaires and equipment was delivered to the local game post or Ikorongo Grumeti Game Reserve headquarters. In 17\% of the 201 patrols during the survey period District Game Scouts accompanied the VGS.

Information from the questionnaires, together with household data for the Project villages from the most recent, 1993, census for the area (Kauzeni \& Kiwasila, 1994), was used to quantify the economic value of illegal hunting. To determine the number of illegal hunters originating from all 14 Project villages combined we calculated the proportion of the local residents engaged in hunting in protected areas, as a function of the distance of the home village from the boundary of the nearest protected area border (Appendix 2). Distances were determined using the 1:50,000 topographic maps of the Surveys and Mapping Division, Ministry of Lands, Houses and Urban Development. By multiplying, for each village, the proportion of local residents engaged in hunting by the village population size, we derived an estimate of the total number of hunters in the 14 Project villages.

Through discussions with a total of 41 VGS and district game scouts we determined the price of dried and fresh meat in the Project villages that was derived from illegal hunting (the game meat of species with body sizes greater than impala is usually sold or bartered as dried meat, whereas that of smaller species is usually sold as fresh meat). Using this information we determined the mean annual economic value of game meat to a hunter (Appendix 2), and multiplied this by the estimate of the total number of hunters to obtain an estimate of the total economic value of illegal hunting to the 14 Project villages. When estimating the economic 
Table 2 The number and total dressed carcass weight in kg of wildebeest, zebra and topi allocated to the 14 Project villages from the July 1999 game cropping trip with, for each village, its population size, distance from the nearest protected area, number of households, proportion of residents per household hunting (see text and Appendix 2 for details), and estimated number of hunters.

\begin{tabular}{|c|c|c|c|c|c|c|c|c|c|c|c|}
\hline \multirow[b]{2}{*}{ Village } & \multicolumn{2}{|c|}{ Wildebeest } & \multicolumn{2}{|c|}{ Zebra } & \multicolumn{2}{|c|}{ Topi } & \multirow{2}{*}{$\begin{array}{l}\text { Population } \\
\text { size } \\
\text { (1993 census) }\end{array}$} & \multirow{2}{*}{$\begin{array}{l}\text { Distance from } \\
\text { nearest } \\
\text { protected } \\
\text { area }(\mathrm{km})^{\mathrm{a}}\end{array}$} & \multirow{2}{*}{$\begin{array}{l}\text { No. of } \\
\text { households }\end{array}$} & \multirow{2}{*}{$\begin{array}{l}\text { Proportion } \\
\text { of residents } \\
\text { hunting }(y)^{\mathrm{b}}\end{array}$} & \multirow{2}{*}{$\begin{array}{l}\text { No. of hunters } \\
\left(=y^{*} \text { population }\right. \\
\text { size })\end{array}$} \\
\hline & no. & $\mathrm{kg}$ & no. & $\mathrm{kg}$ & no. & $\mathrm{kg}$ & & & & & \\
\hline Robanda & 2 & 154 & - & - & - & - & 1,582 & 4 & 150 & 0.119 & 188.3 \\
\hline Nyichoka & 2 & 141 & - & - & - & - & 1,956 & 8 & 365 & 0.068 & 133.0 \\
\hline Nyakitono & 2 & 150 & - & - & - & - & 1,065 & 8 & 184 & 0.068 & 72.4 \\
\hline Natta-Mbiso & 3 & 175 & 1 & 75 & - & - & 2,119 & 5 & 294 & 0.104 & 220.4 \\
\hline Motukeri & 2 & 139 & 1 & 128 & - & - & 3,316 & 6 & 257 & 0.090 & 298.4 \\
\hline Singisi & 1 & 53 & - & - & 2 & 112 & 1,525 & 1.5 & 176 & $0.147^{c}$ & 224.2 \\
\hline Iharara & - & - & - & - & 2 & 127 & 1,810 & 6.5 & 192 & 0.084 & 152.0 \\
\hline Kyandege & - & - & - & - & 3 & 158 & 5,600 & 9.5 & 778 & 0.056 & 313.6 \\
\hline Mugeta & 2 & 146 & - & - & 1 & 74 & 3,300 & 12 & 458 & 0.039 & 128.7 \\
\hline Mariwanda & 4 & 202 & - & - & 2 & 101 & 3,274 & 6.5 & 408 & 0.084 & 275.0 \\
\hline Kihumbu & 4 & 247 & - & - & 1 & 53 & 1,850 & 5.5 & 200 & 0.097 & 179.5 \\
\hline Hunyari & 4 & 233 & 1 & 101 & 1 & 34 & 4,800 & 6 & 364 & 0.090 & 432.0 \\
\hline Mihale & 2 & 180 & - & - & - & - & 2,280 & 2 & 335 & $0.147^{\mathrm{c}}$ & 335.2 \\
\hline Nyamatoke & 3 & 249 & - & - & - & - & 2,185 & 2.5 & 321 & 0.147 & 321.2 \\
\hline Total & 31 & 2,069 & 3 & 304 & 12 & 659 & 36,662 & & 4,482 & & $3,273.9$ \\
\hline
\end{tabular}

${ }^{a}$ Measured from the centre point of the project village to the boundary of the closest protected area.

${ }^{\mathrm{b}}$ Calculated using equation 1 in Appendix 2.

${ }^{\mathrm{c}}$ When calculating $y$ for villages $<2.5 \mathrm{~km}$ from the nearest protected area, distance was set to $2.5 \mathrm{~km}$ (see Appendix 2 for details).

value we disregarded the value of the animal skins. Because they are evidence of illegal hunting they are usually discarded before hunters return to the villages (J. Wilton, pers. comm.).

SPSS 8.0 (SPSS, Inc., Chicago, USA) was used for all statistical analyses.

\section{Results}

\section{The economics of the cropping operation}

Due to the limited record keeping by SRCP we obtained complete records for only one cropping trip, for July 1999 (Table 2). Cropping trips are budgeted to take a fortnight and usually consist of two game scouts and a Project officer, but consisted on this occasion of three game scouts because a Project officer was not available. The Project villages normally cover half of the ammunition cost, but in the calculations presented here (Table 3) this is incorporated into the total ammunition cost.

On this trip a total of 46 animals were shot (Table 2), and on average the marksman used 4.3 rounds of ammunition per animal. Data was not available on the number of animals wounded and not recovered as carcasses, or on the sex and age of the cropped animals. With an estimated income of US $\$ 1,016$ and total expenses of US $\$ 1,673$, this cropping trip had a deficit of US $\$ 657$ (Table 3). Income from the sale of skins was
Table 3 Total income, total expenses and balance (US \$) from the July 1999 game cropping trip (see Table 2).

\begin{tabular}{|c|c|c|}
\hline Item & Details $^{c}$ & US \$ \\
\hline Total income $e^{\mathrm{a}}$ & $\$ 0.335$ per $\mathrm{kg}^{*} 3,032 \mathrm{~kg}$ & $1,015.7$ \\
\hline \multicolumn{3}{|l|}{ Expenses } \\
\hline Staff Salaries & $\$ 1.72$ per day* $3 \mathrm{GS}^{*} 15$ days & 77.4 \\
\hline \multirow[t]{2}{*}{ Staff Allowances } & 8 days* 3 GS $^{*} \$ 11.33$ & 271.9 \\
\hline & 6 days $* 3 G^{*} \$ 8.67$ & 156.1 \\
\hline Fuel & 280 litres $* \$ 0.67$ & 187.6 \\
\hline Emergency fund & & 40.0 \\
\hline \multirow[t]{2}{*}{ Ammunition } & $\begin{array}{l}56 \text { rounds }(0.303) \text { at } \$ 1.33 \\
\text { per round }\end{array}$ & 74.5 \\
\hline & $\begin{array}{l}140 \text { rounds }(0.220) \text { at } \$ 0.67 \\
\text { per round }\end{array}$ & 93.8 \\
\hline $\begin{array}{l}\text { Vehicle maintenance } \\
\text { cost }^{\mathrm{b}}\end{array}$ & $\$ 0.54$ per $\mathrm{km}^{*} 1,429 \mathrm{~km}$ & 771.7 \\
\hline Total expenses & & $-1,672.9$ \\
\hline Balance & & -657.2 \\
\hline
\end{tabular}

a There is no monitoring of income from the sale of meat in the villages, and therefore the figures are estimated on the basis of the total weight of meat given to each village.

b Taken from Hough (1993) and adjusted for inflation.

${ }^{\mathrm{c}} \mathrm{GS}=$ game scout.

not incorporated as few skins are sold due to marketing difficulties and poor quality. If the annual quota for 1999 (Table 1) had been fully utilized it would have yielded a total value of US $\$ 10,735$ at US $\$ 0.335$ per $\mathrm{kg}$ but, using the mean annual utilization of $43.9 \%$, the value realized for 1999 would have been only US $\$ 4,713$. 


\section{Estimated economic value of illegal hunting}

The VGS conducted 201 patrols from December 1998 to August 1999, both during the day and night, with a mean of $20.8 \pm$ SE 0.3 patrols per month, and arrested an average of $0.5 \pm$ SE 0.1 illegal hunters per patrol. A total of 634 snares (a mean of $3.1 \pm$ SE 0.4 snares per patrol) were collected. Thirty-two pitfall traps were recorded, but no firearms were reported. The VGS observed a total of 111 hunting groups, with a mean of $3.8 \pm$ SE 0.6 hunters per group. During these patrols a total of 96 hunters from 13 tribes, all male, were apprehended for hunting without a licence, and 80 of these answered questions put to them (Appendix 1) about their illegal hunting. The arrested hunters originated from 23 different villages in the Mara Region, both Project and other villages. The mean straight line distance from an 'arrest site' (the centre point of the location name recorded by the VGS) to hunters' home villages was $13.9 \pm \mathrm{SE} 1.6 \mathrm{~km}$, maximum $60.5 \mathrm{~km}(\mathrm{n}=76)$. Of the hunters who replied to the reason for hunting $(n=71)$, $60.5 \%$ stated that they hunted for their own consumption, $8.5 \%$ that they hunted only for profit, and $31 \%$ that they hunted for both purposes. A total of 88 animals of eight species were found with the arrested hunters (81\% migratory animals and 19\% resident) (Table 4 ).

The hunters spent $3.9 \pm$ SE 0.5 days $(n=62)$ out hunting before being caught, and the stated length of an average hunting trip was $6.8 \pm$ SE 0.8 days $(n=52)$. The mean number of annual trips per hunter was $12.9 \pm$ SE 1.8 (range $1-44, \mathrm{n}=41$ ). On average a hunter killed $0.92 \pm$ SE 0.1 animal per trip. The average annual wildlife harvest per hunter was therefore found to be 11.9 animals per year: 9.6 migratory and 2.3 resident. The hunters went on significantly more hunting trips during the dry season than the wet season (Mann Whitney, $Z=-2.358, P=0.018$ ).

Using the commercial prices of meat from animals hunted illegally (Table 5) the mean annual economic value of the wildlife harvest per hunter (E, Appendix 2) was calculated to be US $\$ 64.8 \pm 95 \%$ CI 18.5. We estimated that a total of 3,274 hunters (Table 2), who harvested 38,960 animals, originated from the 14 Project villages. Using this and the estimated mean annual economic value of game meat to a hunter gives an estimated total economic value for the illegal wildlife harvest of

Table 4 Numbers of each of the eight species recovered from 96 illegal hunters, categorized according to the reasons given by the hunters for hunting each species, and the migratory or resident status of each species.

\begin{tabular}{|c|c|c|c|c|c|c|}
\hline \multirow[b]{2}{*}{ Species } & \multirow[b]{2}{*}{ Status } & \multicolumn{4}{|c|}{ Reason given for hunting } & \multirow[b]{2}{*}{ Total } \\
\hline & & Own consumption & Market & Both & Unknown & \\
\hline Wildebeest Connochaetes taurinus & migratory & 20 & 1 & 7 & 11 & 39 \\
\hline Thomson's gazelle Gazella thomsoni & migratory & 25 & 2 & - & 2 & 29 \\
\hline Impala Aepyceros melampus & resident & 5 & - & 5 & 1 & 11 \\
\hline Zebra Equus burchelli & migratory & 1 & - & 2 & - & 3 \\
\hline Warthog Phacochoerus aethiopicus & resident & - & - & 3 & - & 3 \\
\hline Topi Damiliscus korrigum & resident & - & - & 1 & - & 1 \\
\hline Reedbuck Redunca redunca & resident & 1 & - & - & - & 1 \\
\hline Gray duiker Sylvicapra grimmia & resident & 1 & - & - & - & 1 \\
\hline Total & & 53 & 3 & 18 & 14 & 88 \\
\hline
\end{tabular}

Table 5 Commercial price (US \$, see text for details) of the meat of the eight species hunted illegally.

\begin{tabular}{|c|c|c|c|}
\hline \multirow[b]{2}{*}{ Species } & \multirow[b]{2}{*}{ No. of pieces per carcass } & \multicolumn{2}{|c|}{ Total value of carcass \pm SE } \\
\hline & & Wet season & Dry season \\
\hline \multicolumn{4}{|l|}{ Prices for dried meat } \\
\hline Zebra Equus burchelli & 15 & $21.5 \pm 3.0$ & $12.3 \pm 1.5$ \\
\hline Wildebeest Connochaetes taurinus & 11 & $10.3 \pm 1.8$ & $5.7 \pm 1.0$ \\
\hline Topi Damiliscus korrigum & 11 & $10.3 \pm 1.8$ & $6.0 \pm 1.0$ \\
\hline \multicolumn{4}{|l|}{ Prices for fresh meat } \\
\hline Impala Aepyceros melampus & 6 & $8.3 \pm 1.3$ & $5.4 \pm 1.1$ \\
\hline Warthog Phacochoerus aethiopicus & 6 & $8.6 \pm 1.2$ & $5.6 \pm 1.0$ \\
\hline Reedbuck Redunca redunca & 6 & $8.3 \pm 1.3$ & $5.4 \pm 1.1$ \\
\hline Thomson's gazelle Gazella thomsoni & 4 & $4.4 \pm 0.6$ & $2.7 \pm 0.6$ \\
\hline Gray duiker Sylvicapra grimmia & 4 & $4.4 \pm 0.6$ & $2.7 \pm 0.6$ \\
\hline
\end{tabular}


US $\$ 212,155 \pm 95 \%$ CI 60,569 . Using a conservative estimate of one adult male per household, illegal hunters constitute $73 \%$ of the adult male population of the Project villages (Table 2).

\section{Discussion}

Game cropping has been proposed and used as a means of giving rural communities economic benefits from living next to protected areas in Africa (Myers, 1981; Mbano et al., 1995), although caution has been urged in exercising this approach (Parker, 1984; Macnab, 1991; Barrett \& Arcese, 1995). The SRCP cropping operation has been running for several years, but the percentage of the quota utilized has generally been low (Table 1). Both Ikorongo and Grumeti Game Reserves and surrounding non-protected areas, where the cropping takes place, are over-exploited and contain little resident wildlife (Cambell \& Borner, 1995). Cropping is therefore largely dependent on migratory herds, which only spend brief periods in the cropping area. These facts, together with logistical problems such as the use of only one vehicle, the long distances involved and poor infrastructure, explain why the utilization of the quota remains low. In addition, the quota for each of the 14 Project villages is small, which limits the cropping scheme's impact on individual villages. As illegal hunting generates an economic value 45 times greater than that derived from the cropping operation, the latter is therefore, in itself, unlikely to put an end to illegal hunting.

The running cost of the July 1999 cropping operation exceeded the revenue that it generated, but it could be argued that this single trip is not representative of the whole cropping season. However, we believe that the deficit from the trip is probably an underestimate of the general deficit because: (1) game cropping undertaken after migratory animals move out of the area will yield fewer animals, (2) the distance travelled during each cropping trip will increase after the migratory herds move on because animals become harder to locate and more wary, and (3) planning costs, the inclusion of a Project officer during cropping, and the purchase of the vehicle and firearms are not included in the cost estimate. Although the cropping operation runs at a deficit, SRCP covers all costs and therefore cropping still remains lucrative to the Project villages who retain all income generated from the sale of meat.

A large number of bullets were used per animal on the July 1999 cropping trip (4.3 rounds). This low efficiency may be due to: (1) unreported carcasses, (2) poor marksmanship, (3) difficult cropping conditions (large flight distance, difficult terrain and daylight cropping), and (4) the absence of a Project officer on the trip. By comparison Mphande \& Jamusana (1984) stated that the culling of nyala antelopes Tragelaphus angasi in Malawi, conducted at night with the use of a spotlight, used on average only 1.03 rounds per animal.

Although fresh meat from the cropping operation is cheaper (US $\$ 0.27-0.40$ per $\mathrm{kg}$ ) than locally bought beef (US \$1.1 per kg), the poorer households may still not have cash, and it is therefore the relatively affluent households that are able to more readily take advantage of the availability of legal fresh game meat. The utilization of wildlife resources by local communities is often both for household consumption and income (Marks, 1973; Campbell \& Hofer, 1995; Carpaneto \& Fusari, 2000). The majority of the illegal hunters arrested during the patrols stated they were hunting for their own consumption. Wildlife food sources are important locally because several of the villages in the study area do not have a sufficient supply of food crops to survive only on agriculture (Iwai, 1997; Mtoni, 1999). However, the data collected needs to be treated cautiously, as the hunters may have been afraid of replying that they hunted for income, and subsistence hunters who hunt illegally to supply their family with meat may also switch to commercial hunting (for sale or barter), depending on the demand for game meat and the degree of poverty in their household (Hofer et al., 1996; Barrett \& Arcese, 1998).

Our method of collecting information on illegal hunting could have introduced biases in the calculations of our estimates. Because the dry season months of September-November were not included we may have underestimated the mean economic value of game meat to each hunter. Furthermore, arrested hunters may have under-reported the number of animals killed during hunting trips and the number of hunting trips in each season, because of fear of punishment (although arrested hunters were not punished according to their level of hunting). Although Rugumayo (1996) reported that illegal hunting from the Project villages is on the decline, which could weaken the model of Campbell \& Hofer (1995) the proportion of local residents per household engaged in hunting (Appendix 2), the level of hunting activity around the Project villages suggests that the model is still valid.

In recent years SRCP, together with the community conservation programme of Tanzania National Parks, has worked extensively with local communities around the Serengeti National Park to raise awareness about hunting issues and to encourage the establishment of small-scale economic projects. SRCP has also helped some of the Project villages organise wildlife management areas, which may generate income in the future, and trophy hunting and photo safaris could provide a further source of income. Such initiatives may not, 
however, necessarily provide sufficient incentives for the cessation of illegal hunting, as it also has cultural and recreational motives that remain unaddressed (Gibson \& Marks, 1995; Lewis \& Phiri, 1998; Infield, 2001).

To be able to improve the long-term conservation of the Serengeti ecosystem, managers need to address the cause and not the symptoms of illegal hunting. Widespread poverty provides the incentive for illegal hunting, and hunting will continue as long as alternative sources of income are unavailable. The SRCP game cropping has small quotas for each Project village, generates little revenue, and involves Project villages to only a limited degree. It will not be able to sustain itself beyond donor support. We therefore recommend that SRCP discards the game cropping operation in favour of a diversification of income opportunities for the Project villages in areas such as agriculture and tourism. In this context SRCP needs to continue its cooperation with organizations that have adequate expertise in extension services.

\section{Acknowledgements}

We thank Jotham Wilton, Stephen Kitenyi and Fredrick Mombek for providing information on legal hunting in the study area. Logistical support for the study was provided by SRCP. We thank Anne Kari Evjen Olsen and Christian Von Essen Pedersen, Joseph Warioba, Nolasco Ngowe, Shabani Majiyapwani, Julius Lameck and the SRCP staff for friendship, help and hospitality while in Fort Ikoma, the Project villages and the Village Game Scouts who agreed to participate in the study, and Scott Armbruster, Bjørn Kaltenborn, Graciela Rusch, Bård G. Stokke, Ken Campbell and two anonymous reviewers for their comments. We are grateful to the Tanzania Wildlife Research Institute and Commission for Science and Technology for permission to conduct the study, which was part of a MSc at the Norwegian University of Science and Technology.

\section{References}

Adam, W.M. \& Hulme, D. (2001). If community conservation is the answer, what is the question? Oryx, 35, 193-201.

Arcese, P., Hando, J. \& Campbell, K. (1995) Historical and present day anti-poaching efforts in Serengeti. In Serengeti II - Dynamics, Management, and Conservation of an Ecosystem (eds A.R.E. Sinclair \& P. Arcese), pp. 506-533. University of Chicago Press, Chicago. USA.

Barrett, C.B. \& Arcese, P. (1995) Are integrated conservationdevelopment projects (ICDPS) sustainable? On the Conservation of large mammals in sub-Saharan Africa. World Development, 23, 1073-1084.
Barrett, C.B. \& Arcese, P. (1998) Wildlife harvest in integrated conservation and development projects: linking harvest to household demand, agricultural production, and environmental shocks in the Serengeti. Land Economics, 74, 449-65.

Bergin, P. (2001) Accomodating new narratives in a conservation bureaucracy: TANAPA \& community conservation. In African Wildlife and Livelihoods: The Promise and Performance of Community Conservation (eds D. Hulme \& M. Murphree), pp. 88-105. James Curry, Oxford and Heinemann, New Hampshire.

Bureau of Statistics (1988) Population Census: Preliminary Report. Ministry of Finance, Economic Affairs and Planning, Dar es Salaam, Tanzania.

Campbell, K.L.I. \& Borner, M. (1995) Population trends and distribution of Serengeti herbivores: implications for management. In Serengeti II - Dynamics, Management, and Conservation of an Ecosystem (eds A.R.E. Sinclair \& P. Arcese), pp. 117-145. University of Chicago Press, Chicago. USA.

Campbell, K.L.I. \& Hofer, H. (1995) People and wildlife: spatial dynamics and zones of interaction. In Serengeti II Dynamics, Management, and Conservation of an Ecosystem (eds A.R.E. Sinclair \& P. Arcese), pp. 534-570. University of Chicago Press, Chicago. USA.

Carpaneto, G.M. \& Fusari, A. (2000) Subsistence hunting and bushmeat exploitation in central-western Tanzania. Biodiversity and Conservation, 9, 1571-1585.

Child, G. (1996) The role of community-based wild resource management in Zimbabwe. Biodiversity and Conservation, 5, 355-367.

Dublin, H.T., Sinclair, A.R.E., Boutin, S., Anderson, E., Jago, M. \& Arcese, P. (1990) Does competition regulate ungulate populations? Further evidence from Serengeti, Tanzania. Oecologia, 82, 283-288.

Gibson, C.C. \& Marks, S.A. (1995) Transforming rural hunters into conservationists- an assessment of community-based wildlife management programs in Africa. World Development, 23, 941-957.

Hackel, J.D. (1999) Community Conservation and the future of Africa's wildlife. Conservation Biology, 13, 726-734.

Havnevik, K.J., Monela, G., Jingu, R., Rugumayo, C.R. \& Røskaft, E. (2001) Management of Natural Resources Programme, Tanzania, Phase II (1998-2002). Mid-term Review. Report presented to the Royal Norwegian Embassy, Dar es Salaam and the Ministry of Natural Resources and Tourism, Tanzania.

Herlocker, D. (1976) Woody Vegetation of the Serengeti National Park. Texas A \& M University, College Station, USA.

Hofer, H., Campbell, K.L.I., East, M.L. \& Huish, S.A. (1996) The impact of game meat hunting on target and non-target species in the Serengeti. In The Exploitation of Mammal Populations (eds J. Taylor \& N. Dunstone), pp. 117-146. Chapman and Hall, London, UK.

Hofer, H., Campbell, K.L.I., East, M.L. \& Huish, S.A. (2000) Modeling the spatial distribution of the economic costs and benefits of illegal game meat hunting in the Serengeti. Natural Resource Modeling, 13, 151-177.

Holmern, T. (2000) Hunting and community-based conservation outside the Serengeti National Park - A sustainable approach by Serengeti Regional Conservation Project (SRCP)? MSc thesis, Norwegian University for Science and Technology, Trondheim, Norway. 
Hough, J.L. (1993) Community Hunting Experiments. Unpublished technical report. Report no. 2, Serengeti Regional Conservation Strategy, Tanzania.

Hulme, D. \& Murphree, M. (eds) (2001) African Wildlife and Livelihoods - The Promise and Performance of Community Conservation. James Curry, Oxford and Heinemann, New Hampshire, USA.

Infield, M. (2001) Cultural values: a forgotten strategy for building community support for protected areas in Africa. Conservation Biology, 15, 800-802.

Iwai, Y. (1997) Subsistence strategies of households in Robanda Village adjacent to Serengeti National Park, Tanzania. MA thesis, Kyoto University, Kyoto, Japan.

Kauzeni, A.S. \& Kiwasila, H.L. (1994) Serengeti Regional Conservation Strategy: a Socioeconomic Study. Institute of Resource Assessment, University of Dar es Salaam, Dar es Salaam, Tanzania.

Kiss, A. (ed.) (1990) Living with Wildlife: Wildlife Resource Management with Local Participation in Africa. Technical Paper Number 130, World Bank, Washington, DC, USA.

Lewis, D.M. \& Alpert, P. (1997) Trophy hunting and wildlife conservation in Zambia. Conservation Biology, 11, 59-68.

Lewis, D.M., Kaweche, G.B. \& Mwenya, A. (1990) Wildlife conservation outside protected areas - lessons from an experiment in Zambia. Conservation Biology, 4, 171-180.

Lewis, D.M. \& Phiri, A. (1998) Wildlife snaring - an indicator of community response to a community-based conservation project. Oryx, 32, 111-121.

Maddock, L. (1979) The 'migration' and grazing succession. In Serengeti, Dynamics of an Ecosystem (eds A.R.E. Sinclair \& M. Norton-Griffiths), pp. 104-129. University of Chicago Press, Chicago, USA.

Marks, S.A. (1973) Prey selection and annual harvest of game in a rural Zambian community. East African Wildlife Journal, 11, 113-128.

Mbano, B.N.N., Malpas, R.C., Maige, M.K.S., Symonds, P.A.K. \& Thompson, D.M. (1995) The Serengeti Regional Conservation Strategy. In Serengeti II - Dynamics, Management, and Conservation of an Ecosystem (eds A.R.E. Sinclair \& P. Arcese), pp. 605-616. University of Chicago Press, Chicago, USA.

Macnab, J. (1991) Does game cropping serve conservation? A re-examination of the African data. Canadian Journal of Zoology, 69, 2203-2290.

McNaughton, S.J. \& Banyikwa, F. (1995) Plant communities and herbivory, In Serengeti II - Dynamics, Management, and Conservation of an Ecosystem (eds A.R.E. Sinclair \& P. Arcese), pp. 49-70. University of Chicago Press, Chicago, USA.

Mphande, J.N.B. \& Jamusana, H.S. (1984) Culling of nyala antelopes in Lengwe National Park, Malawi. In Conservation and wildlife resources in Africa (eds R.H.V. Bell \& E. McShaneCaluzi), pp. 256-277. Peace Corps, Washington, DC, USA.

Mtoni, P.E. (1999) Involve them or lose them both: local communities surrounding Serengeti National Park in Bunda and Serengeti Districts in relation to wildlife conservation. MSc thesis, Agricultural University of Norway, Ås, Norway.

Myers, N. (1981) The canning of Africa. Science Digest, 8, $72-119$.

Newmark, W.D. \& Hough, J.L. (2000) Conserving wildlife in Africa: integrated conservation and development projects and beyond. Bioscience, 50, 585-592.
Parker, I.S.C. (1984) Perspectives on wildlife cropping or culling. In Conservation and Wildife Resources in Africa (eds R.H.V. Bell \& E. McShane-Caluzi), pp. 233-253. Peace Corps, Washington, DC, USA.

Rugumayo, C.R. (1996) Participation in Sustainable Resource Utilisation and Benefit Sharing. The Case of Serengeti Regional Conservation Strategy, Tanzania. NIBR Working Paper, Oslo, Norway.

Songorwa, A.N. (1999) Community-based wildlife management (CWM) in Tanzania: are the communities interested? World Development, 27, 2061-2079.

Songorwa, A.N., Buhrs, T. \& Hughey, K.F.D. (2000) Communitybased wildlife management in Africa: a critical assessment of the literature. Natural Resources Journal, 40, 603-643.

SRCS (Serengeti Regional Conservation Strategy) (1995) Implementation Report of the Development Activities for the Financial Year 1995/96. Unpublished report. Ministry of Natural Resources and Tourism (Wildlife Division), Tanzania.

Walsh, M. (1998) Notes for Mbomipa Project Visitors. Unpublished report no. MMN1, August 1998. Ministry of Natural Resources and Tourism (Wildlife Division), Tanzania. World Bank (2000) Data and Statistics: GNI per capita 2000, Atlas method and PPP. http://www.worldbank.org/data/ databytopic/GNPPC.pdf [accessed 6 August 2002].

\section{Biographical sketches}

Tomas Holmern is interested in natural resource management. He is currently working as a consultant for the Department of Zoology, Norwegian University for Science and Technology.

Eivin Røskaft is a behavioural ecologist interested in a wide range of bird species in Europe, North America and Africa, and in the conflict between humans and mammals over the use of limited land.

Job Mbaruka is interested in management of natural resources and sustainable agriculture. He served as the director of Serengeti Regional Conservation Project during 1997-2000, and is currently a member of the Tanzanian parliament.

\section{Appendix 1}

Appendix 1 for this article is available online at http:/ /journals.cambridge.org

\section{Appendix 2}

The proportion $y$ of the local residents of a village engaged in hunting in the nearest protected area was calculated as:

$y=0.208 e^{-0.139 x}$

where $x$ is the distance in $\mathrm{km}$ from the village to the nearest protected area border (Serengeti National Park, Ikorongo Game Reserve or Grumeti Game Reserve). This function was determined (Campbell \& Hofer, 1995) from a best fit curve for 10 villages that lay $2.5-48 \mathrm{~km}$ from 
a protected area. The function declines exponentially with the distance of the village from the protected area. Because Campbell \& Hofer (1995) did not utilize data from villages $<2.5 \mathrm{~km}$ from a protected area, for the two villages that were closer than this distance (Table 2) $x$ was set at 2.5 .

The mean annual economic value of game meat $(E)$ to a hunter was calculated as

$E=\left\{\sum_{i=1}^{7}\left[\left(\frac{5}{12} S p_{i} P w_{i} K\right)+\left(\frac{7}{12} S p_{i} P d_{i} K\right)\right]\right\}+\left\{S p_{w} P_{w} K\right\}$ where $i$ are the seven species taken by hunters that are available in both the dry (June-December, i.e. 7 months) and wet (January-May, i.e. 5 months) seasons, $S p_{i}$ is the proportion that each species contributes to the average wildlife harvest for each hunter as derived from the total number of animals confiscated from arrested hunters (Table 4), $P w_{i}$ and $P d_{i}$ are the game meat prices in the wet and dry season respectively, and $K$ is the mean number of animals taken per year per hunter. Wildebeest, $w$, is only available in the study area in the dry season (Maddock, 1979). We assumed that, except for wildebeest, the availability of all species was the same regardless of season. 


\title{
Uneconomical game cropping in a community-based conservation project outside the Serengeti National Park, Tanzania
}

\author{
Tomas Holmern, Eivin Røskaft, Job Mbaruka, Samson Y. Mkama and John Muya
}

\section{Appendix 1}

This is an English translation of the questionnaire, originally written in KiSwahili, used by Village Game Scouts in the survey of illegal hunting carried out from December 1998 to August 1999 (see text for details).

Village Game Scout Poaching Survey
A. Name
C. Departure time
D. Duration of patro
B. Village
E. No. of game scouts on patrol

Number

If a wire snare, pitfall or animal is found, answer questions 1-2 and 19-20.

If poacher(s) only observed, answer questions 1-3.

If poacher(s) apprehended, answer questions 1-20.

1. Date

2. Place of capture/finding/observation.

3. No. of poachers observed 4. No. of poachers arrested

5. Name of poacher

7. Age 8. Sex: Male $\square$ female 6. Home village

11. Is the animal hunted for: Own consumption $\square$ Market $\square$ Traditional uses $\square$ Other

12. Average monthly income from hunting in Tanzanian shillings

13. If the meat is for the market, how much do you get for $1 \mathrm{~kg}$ of fresh or dry meat in Tanzanian shillings: Wildebeest Zebra Topi Impala

14. No. of days spent hunting on this trip 15. No. of days spent on an average hunting trip

16. How many trips do you make a) During the dry season b) During the wet season

17. Total number of hunting trips during a year

18. Method of poaching:

Wire $\square$ No.__ ; Spring trap $\square$ No. ; Rope net $\square$ No. ; Pit fall $\square$ No.

Bow $\square$ No._ , Arrows $\square$ No. ; Dog $\square$ No ; Firearm $\square$ No.

Type of firearm_ , No. No. ; Torch $\square$ No. ; Spear $\square$ No.

Other types of weapon $\square$ Specify

$$
\text { o. }
$$
10. Household size

19. Animals caught:

\begin{tabular}{|c|c|c|c|c|c|}
\hline Species & Number & Weight (kg) & Sex & Age & Weapon used \\
\hline & & & & & \\
\hline & & & & & \\
\hline & & & & & \\
\hline & & & & & \\
\hline & & & & & \\
\hline
\end{tabular}

20. Give a description of the place of capture or where the snare/pitfall was found: open grassland $\square$, open woodland $\square$, Dense woodland $\square$, Near the river/riverine vegetation $\square$, Other, specify (If there is not enough room please use the other side of the form) 